\title{
Implementation of Islamic Values in Hospital Management: Islamic General Hospital Boyolali's Case
}

\author{
Kusnulia Rosita, Yan Rachmawati Y. A, Susatyo Yuwono*
}

Faculty of Psychology, Universitas Muhammadiyah Surakarta, 57162, Pabelan, Kec Kartasura, Kabupaten Sukoharjo, Jawa Tengah, Indonesia

*Corresponding author: sy240@ums.ac.id

Article history: Received: 11 January 2020 Received in revised form: 28 June 2020 Accepted: 10 May 2021 Published online: 09 August 2021

\begin{abstract}
Islamic General Hospital X Boyolali applies Islamic-based HR management to his company. The purpose of this paper is to determine the implementation of Islamic values which had been applied by HR management in the process of employee selection and development. This research uses descriptive qualitative method with interviews, observations and documentations collecting data tools. Informants are people in HR department from lowest level to highest level management. As an Islamic hospital whose mission is to provide quality, shar'i and fair health services, the management of hospital always applies Islamic values in developing its human resource potential. Through the inculcation of Islamic values, it is expected that the quality of hospital human resources will improve in terms of devotion, professionalism of work, and welfare for all hospital stakeholders. The results of this study stated that Islamic values can improve discipline and productivity of employee performance. The Islamic aspect is shown by including the criteria for reading the Al-Qur'an and the compulsory reading prayer test in the selection and Al-Qur'an study and daily worship monitoring in employee development.
\end{abstract}

Keywords: Islamic HR Management; Islamic Culture; Selection; Employee Development.

(C) 2021 Penerbit UTM Press. All rights reserved

\subsection{INTRODUCTION}

Organizational development can not be separated from human resource factors to achieve organizational goals (Cummings \& Worley, 2001). Manpower in organizations are people who design or produce goods or services, quality control, products selling, generate profit source, and formulate all strategies and objectives of the organization (Samsudin, 2010).

Discussion about people as the core of the organization is an interesting one. It was seen in various concepts arise in personnel management theme, human resource management to human capital theme. Islamic-based organizations has an islamic values as a base in every decision making company policy. Some organization have difficulties to apply these values because of inappropriate result to organizational culture (Branine and Pollard, 2010).

The concept of Islamic HRM in this organization has not constructed well. Companies need to formulate and improve their own understanding of the importance of developing individuals in the context of working in organizations and institutions (Asrar \& Kuchinke, 2016). The organization is a place to manage $6 \mathrm{M}$ (men, money, methods, materials, machines, and markets) and all management process activities to achieve the goals (Hasibuan, 2001).

Developing organizations means develop its human resources to have a great responsibility, and accordance with all systems which is adopted in the organization (Hasibuan, 2014).

It will influence the way they act (Robbins and Coutler, 2010). In the Islamic perspective, organizational culture must be developed on the Islamic perspective in accordance with the nature and view of Islam regarding humans and humanity. Oktina (2012) stated that Indonesia as a country with a majority moslem population began to apply Islamic values to business activities, including the management of human resources.

A similar study, "The Practice of Implementing Islamic Based Management" by Oktina (2012), shows a different result. Employees which working at PT.Toha Putra had already implemented Islamic-based management. Another research is about "Application of Islamic values in the practice of human resource management," by Isti'adzah (2017) shows that humans play a major role in carrying out management function. A good human resource will help the company achieve its goals. Hasyim (2009) stated that companies which implement Islamic values in human resource management use the Islamic sharia regulations to manage the relation of human resource management functions, as like human resource planning, recruitment, selection, employment contracts, training, performance appraisal, employee development, and compensation.

Good human resources must be followed by high motivation for employees to work to company expectations. Motivation is a process in carrying out a job by involving the competencies possessed, direction from according in line strength and persistence to achieve company goals (Robbins \& Judge, 2015). Work motivation in Islam is not only used to increase employee productivity but also to worship to Allah subhanahu wata'ala (Anoraga \& Prasetyo, 2015). 
Islamic General Hospital $\mathrm{X}$ in Boyolali is the case of this study because it has implemented Islamic values in its business activities, including in human resource management. This business which operates in the health sector has a vision "To become the most beloved Islamic hospital by its quality and care". This vision is derived into several missions providing quality health services, sharia, and justice; being a health promotion hospital; and increase taqwa, professionalism and welfare for all hospital stakeholders. Based on Islamic values, this hospital has become a reference for the community since 2011.

This research aim is exploring information relating to the extent of understanding and application of the Islamic values in management role, especially such as planning, recruitment, selection, employment contracts, training and development, performance appraisal, and compensation. In addition, this paper aims to determine the work motivation given to employees to apply Islamic values in business activities.

\subsection{LITERATURE REVIEW}

\section{Workplace Spirituality}

Workplace spirituality is an effort to find purpose in life in developing strong relationships with fellow employees and other people who are related to work and maintain consistency with one's beliefs and organizational values (Mitroff, Denton, \& Alpaslan, 2009). Workplace spirituality is an understanding of an individual's self as a spiritual being whose soul needs maintenance in the workplace with all the values that exist in him who have experienced work experience, as well as experiencing feelings of being connected with others and the community at work (Ashmos \& Duchon, 2000). Workplace spirituality is a type of psychological climate in which employees see themselves as having an internal life that is cared for with meaningful work and placed in the context of a community. (Duchon \& Plowman, 2005).

Workplace spirituality includes three dimensions, meaningful work (individual level), sense of community (group level), and work alignment organizational values (organizational level) (Milliman et al, 2003). Meaning of work includes three indicators namely enjoy work, energized by work, and work gives personal meaning and purpose. The sense of community dimension has three indicators namely sense of connection with co-workers, employees support each other, and linked with a common purpose. The dimensions of work alignment organizational values have three indicators namely feel connected to the organization's goals, identify with the organization's mission and values, and the organization cares about employees.

Other dimensions of workplace spirituality include employee weel being, sense of meaning and purpose, and sense of community and interconnectedness (Karakas, 2010). The employee weel being dimension has indicators of increasing morale, increasing commitment and productivity, reducing stress, burnout and workaholism. The dimension of sense of meaning purposes has indicators to perform better, more productive, and creative work. The dimensions of sense of community and interconnectedness have indicators namely interpersonal relationships, collective dimensions, and social dynamics of spirituality.

\section{The Meaning of Islamic Based Management}

The concept of spiritual management in the language of K.H Abdullah Gymnastiar was introduced with the term qalbu management (Gymnastiar, 2012), which is based on the religious mindset that places relationships between people in work and business processes, which involve the relationship between humans and God. The expected goal of implementing Islamic values is that humans involved in the business process of their order are based on devotion to Allah SWT.

Human resource management (Handoyo, 1994) is a process of planning, organizing, directing, and supervising the activities of procurement, development, compensation, integration, maintenance, and release of human resources to achieve organizational goals. According to Bohlander and Snell (2007), human resource management is the study of how to empower employees in a company, create jobs, work groups, develop employees and reward them for their service.

Islamic management that is applied in companies can be seen from several indicators, including developing a religious mindset, having a high commitment to duties and obligations, professional, having high moral integrity and constantly innovating (Fauroni, 2006).

Spirituality through Islamic values can make employees more effective at work because in Islam, working is not only a means of earning a living but work is worship.

\subsection{METHODOLOGY}

The research method use case study. The location of the case is Islamic General Hospital X Boyolali in Ngemplak District area, Boyolali Regency. This hospital is the first Islamic hospital in Boyolali, which has been opened services in rural areas and implemented an Islamicbased recruitment system.

Informants

The informant were peoples from all levels of HR Department in the hospital, starting from the lower level to the leaders. The description of informants as seen in Table 1. 
Table 1 Description of informants

\begin{tabular}{llll}
\hline No & Informan & Level & Age \\
\hline 1 & S & Manager & 45 \\
\hline 2 & KR & Koordinator training & 27 \\
\hline 3 & HR & Staff & 30 \\
\hline 4 & RD & Staff & 26 \\
\hline
\end{tabular}

\section{Research Instruments}

Data collection techniques use: (1) Observation, which is observing directly in the field of the HR activities, (2) Interview, which is a dialogue conducted by the interviewer to obtain information from the interviewee, and. (3) Documentation from data source from hospital.

\section{Data Analysis}

The analytical technique that was used in this research is descriptive qualitative analysis with a case study approach. Case study is a research model that discusses a boundary system (bounded system) in one case or several detailed cases. This limitation covers certain location units, in certain time periods and in certain cases. Case studies are carried out with comprehensive data mining of various data sources (Creswell, 2007). The first stage of the data analysis process begins with data condensation which is the process of selecting, focusing on simplifying, abstracting and transforming the 'rough' data that arises from the field notes. The second stage is displaying data or presenting data. Presentation data can be done in the form of narration with pictures, pasted, graphs, tables and so on, adjusted to the type of data. The third stage is verification and conclusion. Since the beginning of collecting data, qualitative researchers have begun to search for data, explaining order, explanation, possible configurations, causal flow and propositions that might be obtained.

\section{Ethics in Research}

Research must meet the ethical rules of research, especially those related to informants. Some things that must be fulfilled by researchers are: first, each informant must obtain informed consent which is the basis of mutual agreement with the researcher (Yin, 2009). The study was also supplemented with a research permit and informed consent from the informants. The second part related to ethics is to protect informants from various things that might be detrimental. The next part is the researcher be careful to protect informants from certain groups, for example children. The last part is protecting the privacy and confidentiality of informants so they can avoid harmful things.

\subsection{RESULTS}

Human resources are the important part of the company. Islamic General Hospital X Boyolali puts human resources as one of the important unit in achieving company goals. To continuously improve professionalism and business performance, an integrated quality development program for human resources has been launched. For this reason, the use of human resource development based on Islamic values is important, because there are administrative functions of the staff, hospital systems, and social media related to regulations both internal and external that can be done directly on the work.

Meeting the needs of Islamic-based human resources is one of the main objectives of hospital management related with the rapid growth of business in the last two years. The results of research data obtained from interviews, observations, and documentation, the research will be described as follows:

\section{Implementation of Islamic Values on Hospital Culture}

The main supporting factor for an organization's success is the values that are the source of energy and the work culture of the company. This is proven by Islamic General Hospital X Boyolali which has a vision to be the most loved Islamic hospital because of its quality and concern. The hospital missions is becoming a health promotion hospital and an Islamic hospital in Boyolali whose emphasis is on the spirit of service, management excellence and nuances of beauty to maximize value to the community .

The vision and mission achievement is supported by values which have developed by human resource management, and supported by its positioning as an based Islamic hospital institution. These must be driven by systems, morals, and creeds in accordance with Islamic sharia principles. Hospital applies the practice of honesty and openness since the beginning of recruitment. Hospital also strict on employees who behave in a way that is not in accordance with the corporate culture, Islamic ethics, and the law.

The appointment of staff and officials who will occupy positions must go through an oral and written oath procession regarding the statements of the five pledges of civilization fighters which must be accounted for with the promise to:

a. We work because of Allah and our love for the messenger of Allah

b. We sincerely serve others

c. We work professionally, carefully, and thoroughly.

d. We uphold brotherhood.

e. We are loyal, passionate and never give up. AllahuAkbar. 
The habits that was shown in this hospital make a clear data that there was an application of human resource management and Islamic value has combined the company's objectives. Ethics, norms, and pledges (promises) must be obeyed by management candidate. It was clear that corporate culture is part of human resource management.

One of rituals or practices which has performed at this hospital is morning briefings. Morning briefings was done every day from 8:00 to 08.20 a.m. with all leaders taking turns to give a talk. Morning briefing conducted by recitations (reading the Qur'an), reading the vision, mission, and pledge of employees and then imitated by all participants of the briefing, prayer reading, speech of motivation, and hand washing exercises

There is also a weekly meeting for leaders which is held every monday from 09.00 to $11.30 \mathrm{WIB}$. This meeting forum is used to discuss any problems that was happened in a week, so it can be resolved quickly. Discussion meeting or musyawarah is suggested in Islam tto reach a compromise from many difference opinions on something.

Another activity is a gymnastics for all hospital employees every saturday at 06:30 to 07:30 which is followed by breakfast together. Furthermore, there are also Islamic religious mentoring activities for all hospital employees which are grouped according to their ability to read the Qur'an. This mentoring activity is carried out once a week accompanied by a religious mentor. In addition, there are still a number of activities that are carried out and become routine activities in each month such as friendship among fellow employees with a rotating system from one house to another in the form of employee recitation and interspersed social gathering; family gathering activities every six months; and Employee Education and Information System / Sistem Informasi \& Edukasi Pekerja) which are routinely held every month between the 12 th and 15 th.

\section{Implementation of Islamic Values on The Recruitment and Selection Process}

The development of human resource in terms of quantity and quality has always been carried out as part of improving and increasing hospital capacity since 2017. Human resources at this hospital which initially only had 10 people then became 30 people, and at 2019 it became 182 people. It is not an easy process. Employee recruitment and selection activities are related to the implications of Islamic-based HR which has implemented in hospital. The recruitment process is carried out through social media or direct publication by posters. Posters were posted on the wall magazines of Islamic university and in the mosques around Solo. The management has chosen the environments where an excellent candidate live.

The recruitment and selection process are started by opening a vacancy which had been approved by the director. All documents be selected by HR department staff. The general requirements as like applied in other company, while the specific requirements have derived from vision and mission, for example all candidate must able to read the Qur'an and prayer readings. The results of the subsequent file selection will be analyzed by the HRD manager. Accepted candidate will be trained in orientation period of 5 days. It can be concluded that the recruitment and selection system of this hospital accordance with Islamic values. It is inline with the company culture of this hospital which has implemented in all activities, including recruitment and selection process.

\section{Implementation of Islamic Values to Develop the Potential of Hospital Employees}

Hospital management continues to improve employee productivity through various training and education programs. This training has designed to increase employee competencies, which have a direct impact on increasing of goal achievement. Training and education are part of reward for employee performance to obtain promotion or career advancement.

There is one term in this hospital which called as Pejuang Peradaban (Civilization Fighters). Pejuang peradaban is a pattern of approach in human resources competencies building process. It can increase effectiveness in implemention of promotion systems, compensation systems, performance evaluation systems, education and training systems, career planning systems, and performance management systems. This human resource competency uses as continuous mapping of talent and profiles.

Hospital management provides learning opportunities for employees fairly both who has long tenure or who has just joined. This training is conducted to support their work to be better and more professional. The training categories provided are divided into 3 program, namely:

a. $\quad$ Employee General Competency Training

Training that must be presented by all employees including support and service teams. There are 4 compulsory training that must be presented, namely Basic PPI (Prevention and Infection Control), Training of Fire Extinguishers utilizing (Alat Pemadam Api Ringan) and Disaster Evacuation, BLS Training (Basic Life Support), and Excellent Service Training.

b. Special Competency Training

This training is more technical. The main objective is to prepare the employees accordance with their profession to work optimally by updating to latest scientific. technological developments and customer demands. This training consists of 3 categories, namely: i.Medical Group Training

This training consists of (1) Training of Officers in Special Rooms such as HCU Training, IBS Training, Hemodialysis Training and (2) Training of Medical Service Units, such as ATLS / ACLS Training, PPGD Training, Ponek Training, ECG Interpretation Training, Invasive Action Training, Drug Mixing Training, Neonate Resuscitation Training, APN Training, Child Growth Training, Intubation and Extubation Training, EEG Training, IPCN Training, ICRA HAIS \& ICRA Building Training, PPI TB Training, Infection Surveillance Training, CSSD Training, and KLB Management Training.

ii. Medical Support Group Training

This training consisted of PPI Nutrition Training, Food Delivery Training, Clinical Nutrition Training, Nutrition Quality Training, Cooking Course Training, Special Diet Training, Medication Error Training, Drug Use Side Monitoring Training, Aseptic Dispensing Training, and ATP Dispensing Training.

iii. $\quad$ Non Medical Group Training

This training is intended for medical support employees such as HRD, Finance, and so on. This training consists of the Primary Guard Training, PPE Training and Body Fluids Cleansing, Filing Training, Operational Training and Laundry Maintenance, Financial Report 
Training, Tax Training, Receivable Collection Training, BPJS Training, K3RS Training, Videography Training, Marketing Training, Health Training, and Complaints Handling Training.

c. Managerial Competency Training

The training is intended to improve managerial skills of managements with the aim of providing soft skills as well as hard skills in carrying out managerial tasks. The trainings included PMKP Training, Leadership Training, Administrative and Reporting Activities training, and Pejuang peradaban Training.

Based on the three categories of training programs, it is divided into 2 types of training, namely:

a. Internal training, which is conducted inhouse by the hospital.

b. Extrenal Training is training where the organizer is not from a hospital. This training is usually done individually according to the needs of each employee in improving competence.

The rapid growth in the number of hospital employees poses a challenge to efforts to prepare graduates of health schools. One important development in 2019 is the inauguration of the VVIP room service facility which carries the concept of friendly, beautiful, modern and Islamic. This facility has a strategic importance given that in order to support business growth going forward, it requires at least quality human resources and competencies according to company culture that require at least 30 hours of training for each employee per year. The concentration of hospital training in the Hospital Training and Education program will be able to overcome the problem of the complexity of training scheduling that has been carried out in various units. The implementation of training centered in the training team is expected to be more effective because participants can concentrate on attending learning sessions with flexible time and comfortable environment. When viewed from the Islamic value of the development or improvement of the ability of employees in accordance with the Word of Allah SWT is Al Qur'an Surah Ar Ra'd verse 11 which means that Allah will not change the fate / condition of a people so that they change the circumstances that exist in themselves.

Implementation of Islamic Values on Employee Employment Contracts

Work agreements given by the hospital management to employees are renewed annually. Human relations at work are often called muamalah, in this case the hospital has implemented the Islamic concept in the employment contract agreement. The employment contract is based on an agreement between the two parties, namely management and employees. The employee is divided into three categories, namely permanent employees, non-permanent employees, and contract employees. Every year there will be a renewal of the work contract. Work contract extension is seen from three main aspects, namely devotion (ketaqwaan), professionalism and welfare. However, the devotion or ketaqwaan aspect is the main aspect that can invalidate the other two aspects. Management will be firm in providing sanctions if the employee concerned leaves the prayer five times. Regulations and aspects of devotion, professionalism, and welfare are contained in the employment contract agreement so that it is known by both parties. Islam outlines the rules of work protection so that there are no practices of violations of rights and obligations that are likely to occur.

Implementation of Islamic Values on Performance Appraisal and Employee Compensation

The performance appraisal system and the awarding of compensation to employees are based on the achievement of the Key Performance Indicator (KPI) and job appraisal. In line with the implementation of human resource management systems based on merit and religion, Management has developed a Compensation Management System which is based on three main aspects namely devotion, professional, and welfare. Devotion (ketaqwaan) includes an increase in employees reading ability on Al-Qur'an, the increase in memorization of the Qur'an, the presence of mentoring, monitoring of yaumi charity consisting of congregational prayers, tahajud prayer, achievement of recitations, and duha prayers. In the professional aspect, it includes daily attendance monitoring, KPI achievement and performance evaluation. Furthermore, the welfare aspect includes monitoring the attendance of morning exercise at least 2 times a month, the SIEP agenda once a month, and the hospital family gathering.

Employee remuneration packages in the form of salaries and support are also regularly evaluated and adjusted for factors that increase the cost of living and hospital income. Overall, employee remuneration strategies are designed to motivate employee performance improvement, retain employees so that they are loyal to the company and attractiveness for prospective employees to join the hospital. One of the benefits for employees who are always monitored is the presence of mentoring and an increase in the number of memorization of the Qur'an given in the form of Umrah. In addition to the aforementioned support, in Shawwal together with the hospital's halal bihalal agenda, there are also awards for employees who during the month of Ramadhan are the most recollected, diluted employees, and highly dedicated employees with prizes in the form of certificates and cash. From this explanation it can be said that the application of HR to performance appraisal and employee compensation is in accordance with Islamic values.

\subsection{DISCUSSION, LIMITATIONS AND CONCLUSION}

Islamic based human resource management has an important role in a company. Through human resource management, companies can plan, organize, implement, and oversee the netting of selection, employee development, industrial relations, maintenance, and granting of employment contracts to employees (Mangkunegara, 2007). Company goals can be achieved if you have good human resource management. A clear career plan will motivate employees to give their maximum abilities to the company. Based on the results of research, management policies and empowerment of human resources is one of the advantages offered to customers. Islamic policy is a policy that is applied because of the the hospital wants to work for worship of Allah SWT. Policy the implemented in daily hospital management practices. Islamic-based human resource management policies implemented by hospitals to maintain relationships between hospital stakeholders that are based on Islamic values. 
The policy of human resource management based on Islamic values is not only aimed at lower level employees but for all stakeholders including general employees, medical staff, specialist doctors, midwives, and others. The Islamic-based human resource policy as chosen by hospital rests on three main aspects, namely devotion, professionalism, and welfare. The cultural values developed at the hospital are always socialized to employees at morning briefings.

The Islamic-based resource policy adopted at Islamic General Hospital X Boyolali is obliging all employees to stop their work except those who are conducting medical services to perform pilgrimage prayers at the hospital mosque. In addition, mentoring activities are held every week with mentoring facilitators for a group of 6-12 people to learn to read the Qur'an and tahsin, routine recitation, friendship and monitoring of yaumi charity.

Daily prayers and morning briefings aim to strengthen knowledge about the vision, mission, pledge of hospital fighters and the principles of devotion. The implementation of Islamic values can also be seen in the style of dressing of hospital employees. Female employees use special uniforms from hospitals that are designed according to Islamic Sharia consisting of headscarves covering the chest, tops that cover the buttocks and skirts are made loose, while for men pants are made loose. In addition, female employees are required to wear socks and neat shoes.

The Islamic management policy adopted by the hospital also binds to the implementation of the Qur'an's mentoring for all hospital employees. If employees do not implement the policy will be subject to sanctions in the form of reprimands, first letter warning until third one. The results of observations in the field found that officers or employees who receive a reprimand periodically if monitoring of the charity yaumi has not improved, especially in prayer five times and the ability to read the Qur'an ' an. The sanctions provided are an attempt to warn employees to be disciplined in carrying out their duties as patient servants and worshiping Allah SWT.

The results found that the application of Islamic-based human resource policies in hospitals was also felt by patients and patient visitors. Every prayer time, in every hallway the chanting of the call to prayer and prayer prayer through the hospital speakers and a spiritual officer who visits the patient to pray for him. The patient and family revealed that the Islamic-based human resource management policy implemented by the hospital also felt its impact on the services provided by the hospital. Based on the statement of the patient and his family is when the medical team enters the treatment room, the medical team give greetings "Assalamualaikum" before providing services to patients, then starting with "Bismillah" and when finished providing services will say "Alhamdulillah" and say greetings "Wassalamualaikum".

Officers and employees become more disciplined and apply Islamic values in providing service to patients and in matters of worship. Officers serve patients in accordance with hospital Standard of Procedures (SOP). For example, the Islamic SOP that is implemented in hospitals is when nurses will take patients to the operating room, nurses will remind patients and their families to pray before undergoing surgery. The clerk or nurse recites al-Fatihah and other prayers before performing medical treatment.

The hospital also has a special policy on patient management, where female patients are sought to handle female nurses and vice versa if the male patients who will handle are male nurses. It is based on Islamic rules that provide limits and warnings for people about contact with someone who is not a muhrim. Nurses, doctors, and hospital staff apply SOP (standard operational procedure) to shake hands and smile while saying hello before asking about the patient's health development.

The practices of applying Islamic based management policies above, are part of the management to become the most superior Islamic general hospital in Boyolali in 2024. In terms of employee development, hospital conducts training based on the Ruhiyah dimension to improve employee competency. In addition, hospital management monitors performance evaluation, understanding of the vision, mission, and pledge of hospital fighters.

\section{Research Limitations and Recommendations}

The subject of this study is limited to only one hospital so that the specific findings appear in the form of the implementation of Islamic values in human resource management such as the application of recruitment and selection, employee promotion, training, performance appraisal and compensation as well as the application of employee employment contracts. The next researcher is expected to use different research methods that use more variables to obtain information and diversity in the results of the study.

\subsection{CONCLUSION}

Management and empowerment of Islamic-based human resources is based on the vision and mission of the hospital. The concepts of management and empowerment are based on Islamic values such as the culture of smiling at others, being friendly to patients, speaking polite words, and saying greetings when taking action to patients. Islamic-based human resource management impacts are felt on the services provided by hospitals. The results of the study found that the patient felt comfortable and protected because of the hospitality and responsiveness of the medical staff. In addition, employees are also given religious provisions by hospitals with the aim that employees have good religious knowledge to be practiced in daily life. The religious activities carried out at the hospital include morning prayers during morning briefings, monthly recitation, Al Qur'an recitation every week, religious studies through hospital speakers, congregational prayers, and hospitality between employees. Islamic-based SOPs are also found on employee clothes that are designed according to Islamic law and women are required to veil.

The Islamic aspects applied by hospitals can also be seen from the system of employee recruitment and selection, employee development in the form of training, promotion, performance evaluation, and industrial relations.

\section{References}

Al Qur'an and its Translation. (2005). Bandung: Syamiil Qur'an.

Anoraga, B., \& Prasetyo, A. (2015). Islamic Work Motivation and Employee Work Ethic Bank Jatim Syariah Branch Surabaya. JESTT, 2(7).

Ashmos, D.P., \& Duchon, D. (2000). Spirituality at Work, a Conceptualization and Measure. Journal of Management Inquiry, 19(2), 134-145. 
Asrar-ul-haq, M., \& Kuchinke, K.P. (2016). Impact of Leadership Styles on Employee's Attitude Towards Their Leader and Performance: Empirical Evidence from Pakistan Banks. Future Bussiness Journal.

Bohlander, George \& Snell, Scott. (2010). Principles of Human Resource Management (15 ${ }^{\text {th }}$ ed.). Mason OH: South Western-Cengage Learning.

Branine, M., \& Pollard, D. (2010). Human Resource Management with Islamic Management Principles: A Dialectic for a Reserve Diffusion in Management. Personnel Review, 39(6), 712-727.

Creswell, J. W. (2007). Qualitative Inquiry and Research Design: Choosing Among Five Approaches (2 ${ }^{\text {nd }}$ ed.). Sage Publications, Inc.

Cummings, T.G., \& Worley, C.G. (2005). Organization Development \& Change. Canada: South Western Cengage Learning.

Duchon, D., \& Plowman, A.T. (2005). Nurturing The Spirit at Work: Impact on Work Unit Performance. The Leadership Wuarterly, 16, 807-833.

Fauroni, L. (2006). Etika Bisnis dalam Al Qur'an. Yogyakarta: Pustaka Pesantren.

Gymnastiar, Abdullah. (2002). Meraih Bening Hati Dengan Manajemen Qalbu. Jakarta: Gema Insani Press.

Handoko, H.T. (1994). Manajemen Personalia Dan Sumber Daya Manusia. Yogyakarta: BPFE.

Hasibuan, M. (2014). Human Resource Management. Jakarta: Bumi Aksara.

Hasibuan, M. (2001). Basic Management, Understanding, and Problems. Jakarta: Bumi Aksara.

Hasyim, J. (2009). Islamic Revival in Human Resource Management Practices Among Selected Islamic Organizations in Malaysia. 2 (3), $251-267$.

Isti'adzah, I. (2017). The Application of Islamic Values in the Practice of Human Resource Management (Study of Muslim Business People on the Ayam Bakar Wong Solo Branch Simongan). Skripsi, University Diponegoro.

Jabani, M, \& Tadjuddin. (2018). Implications Of Human Resource Management Based on Islamic Values (Study with Banks Muamalat Palopo). Journal Of Special Religion Research, 3(1), 13-34. ISSN: 2527-3744.

Mangkunegara, A.P. (2007). Corporate Human Resource Management. Bandung. PT. Remaja Rosdakarya.

Miliman, J., Czaplewski, A., \& Ferguson, J. (2003). Workplace Spirituality and Employee Work Attitude- An Exploratory Empirical Assessment. Journal of Organizational Change Management, 16(4),426-447. https://doi.org/10.1108/09534810310484172

Oktina, L. (2012). The Practice of Applying Islamic Based Management to Companies (Study at PT. Tohan Putra Semarang). Skripsi. Semarang: Perpustakaan UNDIP Semarang

Robbins, S.P., \& Coulter, M. (2010). Management (10 ${ }^{\text {th }}$ ed.). Jakarta: Erlangga.

Robbins, S.P., \& Judge, T.A (2015). Organizational Behavior $\left(16^{\text {th }}\right.$ ed.). Jakarta: Salemba Empat.

Samsudin, S. (2010). Human Resource Management. Bandung: Pustaka Setia.

Sangkala. (2007). Knowledge Management. Jakarta: PT Raja Grafindo Persada.

Tasmara, Toto. (2002). Membudayakan Etos Kerja Islami. Jakarta: Gema Insani

Yin, R. K. (2009). Case Study Research: Design and Methods ( $4^{\text {th }}$ ed.). Thousand Oaks, CA: Sage Publications. 